\title{
Malign Transformation in the Low Grade Astrocytomas and Related Factors
}

\section{Düşük Dereceli Astrositomlarda Kötücül Dönüşüm ve İlişili Faktörler}

Kaan KAMASAK ${ }^{1}$, Mehmet Ali EKICI ${ }^{2}$, Cuneyt GOCMEZ ${ }^{1}$, Bulent TUCER ${ }^{3}$, Seyit Kaan BASARSLAN ${ }^{4}$, Ali KURTSOY3

${ }^{1}$ Dicle University, Faculty of Medicine, Department of Neurosurgery, Diyarbakır, Turkey

${ }_{2}^{2}$ Serket Yilmaz Training and Research Hospital, Department of Neurosurgery, Bursa, Turkey

${ }^{3}$ Erciyes University, Faculty of Medicine, Department of Neurosurgery, Kayseri, Turkey

${ }^{4}$ Mustafa Kemal University, Faculty of Medicine, Department of Neurosurgery, Hatay, Turkey

Correspondence address: Mehmet Ali EKICI / E-mail: mehmetali.ekici@gmail.com

\begin{abstract}
AIM: Retrospective investigation of prognostic factors in low-grade astrocytomas.

MATERIAL and METHODS: In the study, prognostic factors were prospectively identified and assumed to be effective on prognosis, which were reviewed in 67 cases diagnosed as low-grade astrocytoma with craniotomy between May 1998 to December 2005 at Erciyes University Neurosurgery Department. Assessment of demographic, neurologic, radiological, surgical and clinical features of cases and adjuvant therapies and their relationship with prognosis were evaluated. Post-operative cumulative survival of the cases was estimated by using the Kaplan-Meier method. The Log Rank test was used to compare the survival curve of the sub-groups. Multivariate analysis of survival was analyzed by using the Cox regression method.
\end{abstract}

RESULTS: It was seen that malign transformation occurred in 9 patients of subtotal resection group. The difference was statistically significant $(p<0.01)$. malign transformation was detected in one female $(3.2 \%)$ and 8 male patients $(22.2 \%)$. Difference in favor of men was statistically significant $(p<0.05)$. Malignant transformation was detected in 7 of the patients given post-operative radiotherapy, only 2 patients displayed malign transformation in the group which received no radiotherapy. Comparison of groups revealed a significant difference ( $p=0.01$ ).

CONCLUSION: Detection of higher malign transformation rate in cases underwent radiotherapy than those did not and the statistical significance in this meaning mandates to revise treatment plan regarding radiotherapy.

KEYWORDS: Low-grade astrocytoma, Prognostic factors, Malign transformation, Radiotherapy

öz

AMAÇ: Düşük dereceli astrositomlarda prognostik faktörlerin retrospektif olarak araştırılması.

YÖNTEM ve GEREÇLER: Bu çalışmada, Erciyes Üniversitesi Tıp Fakültesi Nöroşirurji Kliniği'nde Mayıs 1998 ile Aralık 2005 tarihleri arasında kraniyotomi sonrası düşük dereceli astrsositom tanısı almıs toplam 67 olgunun prospektif olarak tanımlanan ve prognoz üzerine etkin olabileceği varsayılan prognostik faktörler incelendi. Olguların demografik, nörolojik, radyolojik, cerrahi ve klinik özellikleri ile adjuvan tedavilerinin prognostik kriterler olarak değerlendirmesi ve prognozla olan ilişkileri incelendi. Olguların operasyona alındığı tarihten sonraki kümülatif yaşam süresi, Kaplan-Meier yöntemi kullanılarak belirlendi. Alt gruplara ait hayatta kalış süresi eğrisi, Log Rank testi kullanılarak karşılaştırıldı. Cox regresyon yöntemiyle, olguların hayatta kalışlarına ilişkin çoklu değişkenlerin etkisi analiz edildi.

BULGULAR: Subtotal rezeksiyon grubunun 9 hastasında kötücül dönüşüm görüldü, fark istatistiksel olarak anlamlıydı $(<0,01)$. Bir bayan $(\% 3,2)$ ve 8 erkek $(\% 22,2)$ hastada kötücül dönüşüm tespit edildi aradaki fark istatistiksel olarak anlamlıydı $(\mathrm{P}<0,05)$. Postoperatif radyoterapi verilen 7 hastada kötücül dönüşüm tespit edilirken radyoterapi almayan grupta sadece 2 hastada tespit edildi, gruplar arası karşılaştırmada istatistiksel anlamlı fark ortaya çıktı $(P=0,01)$.

SONUÇ: Radyoterapi alan olgularla, almayanlar kıyaslandığında malign dönüşümün radyoterapi alanlarda daha fazla görülmesi ve istatistiksel olarak farklııı̆ın anlamlı olması radyoterapiyle ilgili tedavi planlarını yeniden gözden geçirmemizi gerektirmektedir.

ANAHTAR SÖZCÜKLER: Düşük evreli astrositom, Klinik seyre etki eden faktörler, Kötücül dönüşüm, Radyoterapi

\section{INTRODUCTION}

Low-grade astrocytomas (LGAs) are tumors that develop in supportive cells in the central nervous system and are the subject of debate regarding treatment. Despite their histological presentation, these tumors cause death in majority of cases, and only $20-30 \%$ of patients have long survival (25). LGAs comprise $15 \%$ of all brain tumors in adults (25). Several studies around the world have demonstrated that the annual incidence of gliomas is 5.4 per 100,000 cases (38). The frequency of LGAs is 0.8 per 100,000 cases in adults (37). In other words, a pathology diagnosis of LGA is made for 1 of every 8 adults diagnosed as brain tumor (9). Adult LGAs 
comprise one-third to half of all adult astrocytomas, and they are more common in younger cases compared to high-grade astrocytomas. More than two-thirds of cases are younger than 40 years of age (33).

There are many issues that perpetuate ambiguity regarding LGAs and await solutions: 1) there is no true picture regarding methods to follow, which include periodical radiological follow-up, surgical resection, surgical resection plus radiotherapy, or radiotherapy alone in cases diagnosed as LGA; 2 ) whether or not it is warranted to confirm a radiological diagnosis by a pathological work-up; 3) lack of a common system used for the pathological classification of such tumors; 4) most studies are retrospective and evaluate different parameters, so there is no homogeneity in these studies, and they are not large enough to reach statistical conclusions; 5) the resection degree in cases undergoing surgery may vary from biopsy to aggressive tumor resection; 6) uncertainty regarding whether radiotherapy should be given to those who undergo surgery; and 7) controversy about performing a second operation or radiotherapy in cases of recurrence.

The mentioned above can be clarified by prospective, multicenter, clinical studies, which will be carried out in the future. In the present study, radiological and neuropathological features were evaluated in cases with malignant transformation, and the effects of resection degree were investigated in these cases.

\section{MATERIAL and METHODS}

In the present study, prognostic factors that were assumed to be effective on prognosis were reviewed in 67 cases diagnosed as low-grade astrocytoma in which tumor resection was performed after craniotomy between May 1998 and December 2005 (fallow up period) at the Erciyes University Neurosurgery Department. Specimens from surgical resections were evaluated by an experienced neuropathologist. Histopathological diagnosis was given according to the 2007 WHO classification of tumors of the central nervous system (Table I) (31). Radiological and clinical features and data regarding the treatment modalities used were obtained from a data sheet that was prepared for this study group.

Age, sex, and Karnofsky Performance Score (KPS) during the study were recorded. Cases were scheduled to record clinical and radiological data at 3-month intervals. In each follow-up visit, a control MRI was obtained and the results were interpreted by an experienced radiologist regarding recurrence and re-growth.

Imaging protocol: CT scans with or without contrast material and an MRI were routinely performed in each case before and after surgery, and the features of the tumors themselves and the proposed prognostic features were identified by an experienced radiologist. These features were listed as tumor density, localization, diameter, enhancement, extent to the contra-lateral hemisphere, sharpness of the margins, and midline shift. All cases underwent CT scan within 4 hours after surgery to diagnose a surgery-related complication that remained clinically asymptomatic. An MRI with or without contrast material was performed within the first 72 hours after surgery to identify the degree of surgical resection as a gross total $(\geq 95 \%)$ and a sub-total $(<95 \%)$, and these images were compared using preoperative and postoperative contrasted T1-weighted MR images and T2W MRI images.

Surgical protocol: All 67 cases were operated on with navigation guidance (Brain Lab, Heimsteten, Germany). Under general anesthesia, after the patient was positioned and a Mayfield Pin-holder skull clamp (OMI Surgical products) was applied, the case was registered to the navigation computer using an infrared camera, and a pointer with reflective marker spheres was adhered to the scalp. A skin incision and craniotomy centered on the lesion were accomplished with the aid of the pointer and the navigation-matched surgical microscope (NC4, Carl Zeiss, Oberkochen, Germany). Before the dural opening and resection, the extensions of the lesion were identified for the appropriate dural opening with the help of a navigation-matched intra-operative ultrasound device (Toshiba Tosbee SSA-240A). The surgical

Table I: WHO Grading of Tumors of the Nervous System

\begin{tabular}{|c|c|c|c|c|}
\hline Astrocytic tumor & I & II & III & IV \\
\hline Subependymal giant cell astrocytoma & * & & & \\
\hline Pilocytic astrocytoma & * & & & \\
\hline Pilomixoid astrocytoma & & * & & \\
\hline Diffuse astrocytoma & & * & & \\
\hline Pleomorphic xanthoastrocytoma & & * & & \\
\hline Anaplastic astrocytoma & & & * & \\
\hline Glioblastoma & & & & * \\
\hline Giant cell glioblastoma & & & & * \\
\hline Gliosarcoma & & & & * \\
\hline
\end{tabular}

From Louis DN, Ohgaki H, Wiestler OD, Cavenee WK, Burger PC, Jouvet A, Scheithauer BW, Kleihues P. The 2007 WHO classification of tumours of the central nervous system. Acta Neuropathol. 114(2):97-109, 2007. 
deviation that occurs due to resection during surgery was corrected with the fusion of 3-dimensional MR images and 2-dimensional intra-operative ultrasound images, and this procedure was continued during the resection in a real-time fashion. In cases in which brain shift occurred, repeated intraoperative ultrasound was applied and the obtained data were iteratively fused with the data obtained preoperatively. With this strategy, the deviation of the navigation tool due to brain shift was minimized. Intra-operative ultrasound was repeated as needed for residual tumor detection. When the appropriate resection was achieved, the operation moved to homeostasis.

Radiotherapy protocol: Of the 17 patients, $25.4 \%$ received RT, which was given according to the NCCN Guidelines (National Comprehensive Cancer Network), whose basic selection criteria were sub-total resection performing patients, and this group of patients, whose ages were over 45 years, had no more operation chances because of basal ganglia and deep white matter involvement. The effective irradiation area was drawn on the mask in the simulator. The radiotherapy was performed by applying 6 million electron volts (MV) with a LINAC teletherapy (Varyan 2300c, U.S.A.) device. The area of the radiotherapy was detected in the postoperative T1 MRI section with contrast enhancement or the hypointense area, and $2 \mathrm{~cm}$ of brain tissue beyond this area were targeted for radiotherapy. The radiotherapy was applied at $54 \mathrm{~Gy} / 27 \mathrm{fr} / 6$ week. In both therapeutic stages, the parallel opposed field technique was used. As a prophylactic against cerebral edema throughout the radiotherapy, each cases received 8-16 mg/ day dexamethasone, which was tapered and discontinued within 2 weeks subsequent to the completion of the therapy.

Statistical analysis: The cumulative survival of the cases after the date of surgery was estimated using the KaplanMeier method. The survival curves of several sub-groups were compared using the log rank test. A multivariate analysis was performed using the Cox regression method. The raw and processed data were estimated at the $95 \%$ confidence interval. In the univariate and multivariate analysis, values that affect survival are indicated as $p<0.05$ and $p<0.01$ if significant or $p>0.05$ if insignificant. The statistical analysis was performed using Statistical Package for the Social Sciences 10.0 (SPSS, Inc., Chicago, IL)

\section{RESULTS}

Table II lists the general data and survival rates of the patients with LGA. The median survival time in relation to sex, age group, histopathological grade, pre- and postoperative

Table II: Median Survival Time for the Independent Factors Related with Prognosis in Low-Grade Astrocytomas

\begin{tabular}{|c|c|c|c|c|c|c|c|}
\hline \multirow{2}{*}{ Factors } & \multirow[t]{2}{*}{ Variable } & \multicolumn{2}{|c|}{ Total } & \multicolumn{2}{|c|}{$\begin{array}{c}\text { Survival rate/n } \\
(91.0 \%)\end{array}$} & \multirow{2}{*}{$\begin{array}{c}\begin{array}{c}\text { Median survival time } \\
\text { (month) }(95 \% \mathrm{CI})\end{array} \\
85(78-91)\end{array}$} & \multirow[t]{2}{*}{$\mathbf{P}$} \\
\hline & & $\mathrm{n}=67$ & $\%$ & $\%$ & $n$ & & \\
\hline \multirow{2}{*}{ Sex } & male & 36 & 53.7 & 86.1 & 31 & $81(70-91)$ & \multirow{2}{*}{$>0.05$} \\
\hline & female & 31 & 46.3 & 96.8 & 30 & $72(65-79)$ & \\
\hline \multirow{2}{*}{ Age groups } & $<40$ & 44 & 65.7 & 95.2 & 42 & 89 (83-95) & \multirow{2}{*}{$>0.05$} \\
\hline & $>40$ & 23 & 34.3 & 82.6 & 19 & $64(54-74)$ & \\
\hline \multirow{2}{*}{ Histopathology } & Grade I & 23 & 34.3 & 100 & 23 & 90 & \multirow{2}{*}{$>0.05$} \\
\hline & Grade II & 44 & 65.7 & 86.4 & 38 & $81(70-92)$ & \\
\hline \multirow{2}{*}{$\begin{array}{l}\text { Preoperative Karnofsky } \\
\text { score }\end{array}$} & $<70$ & 7 & 10.4 & 71.4 & 5 & $71(44-97)$ & \multirow{2}{*}{$>0.05$} \\
\hline & $\geq 70$ & 60 & 89.6 & 93.3 & 56 & 87 (81-93) & \\
\hline \multirow{2}{*}{$\begin{array}{l}\text { Postoperative Karnofsky } \\
\text { score }\end{array}$} & $<70$ & 11 & 16.4 & 81.8 & 9 & 77 (57-97) & \multirow{2}{*}{$>0.05$} \\
\hline & $\geq 70$ & 56 & 83.6 & 92.9 & 52 & $87(80-93)$ & \\
\hline \multirow{2}{*}{$\begin{array}{l}\text { Localization of the tumor } \\
\text { (Eloquent area) }\end{array}$} & Yes & 13 & 19.4 & 76.9 & 10 & 74 (54-93) & \multirow{2}{*}{$>0.05$} \\
\hline & No & 54 & 80.6 & 94.4 & 51 & 71 (67-76) & \\
\hline \multirow{2}{*}{ Contrast enhancement } & Yes & 26 & 38.8 & 97.2 & 25 & $89(82-89)$ & \multirow{2}{*}{$>0.05$} \\
\hline & No & 41 & 61.2 & 87.8 & 36 & $82(73-91)$ & \\
\hline \multirow{2}{*}{$\begin{array}{l}\text { Resection degree } \\
\text { (Postoperative MR finding) }\end{array}$} & Gross total & 30 & 44.8 & 96.7 & 29 & $90(83-97)$ & \multirow{2}{*}{$>0.05$} \\
\hline & Subtotal & 37 & 55.2 & 86.5 & 32 & $80(70-91)$ & \\
\hline \multirow{2}{*}{ Complication } & Yes & 26 & 38.8 & 92.3 & 24 & $72(64-79)$ & \multirow{2}{*}{$>0.05$} \\
\hline & No & 41 & 61.2 & 90.2 & 37 & $83(74-93)$ & \\
\hline \multirow{2}{*}{ Second operation } & Yes & 21 & 31.3 & 95.2 & 20 & $74(67-81)$ & \multirow{4}{*}{$>0.05$} \\
\hline & No & 46 & 68.7 & 89.1 & 41 & $82(72-92)$ & \\
\hline \multirow{2}{*}{ Malign transformation } & Yes & 9 & 13.4 & 88.9 & 8 & $68(55-81)$ & \\
\hline & No & 58 & 86.6 & 91.4 & 53 & $84(77-92)$ & \\
\hline
\end{tabular}


Karnosfsky performance score (KPS), tumor localization, contrast enhancement, degree of resection, re-operation, and malignant transformation are shown. No significant difference was detected regarding median survival time when the variables shown in Table II were analyzed. There were no statistically significant differences according to median survival time for the independent variables $(P>0.05)$.

Sex: Of the 67 patients, 31 (46.2\%) were female, whereas 36 (53.7\%) were male. Overall, 61 patients (91\%) were alive, and the postoperative median survival time (MST) was calculated as 85 months (95\% Cl: 78-91). Of the 36 men, 31 (86.1\%) were alive, and the median survival time was calculated as 81 months (95\% Cl: 70-91), whereas 30 (96.8\%) of the 31 women were alive, and the median survival time was calculated as 72 months (95\% Cl: 65-79).

Age: The median age was 31 years, ranging from 13 to 63 years. As shown in Table II, the cases were classified into two sub-groups according to their age: patients younger than 40 years of age and those age 40 or older. The median survival time was estimated as 89 months (95\% Cl: $83-95)$ for 44 patients younger than 40 years of age, while it was 64 months (95\% Cl: 54-74) for 23 patients age 40 or older

Pathological diagnosis: Grade 1 and 2 tumors assessed with LGA were seen in $23(34.3 \%)$ and 44 (65.7\%) of the patients, respectively. In relation to the mean follow-up period (34 months), of the 61 cases survived, 38 cases (62.3\%) were grade 2, whereas $23(37.7 \%)$ were grade 1 . No deaths were observed among patients with Grade 1 tumors during the follow-up period, and the median survival time was found to be 90 months. It was 81 months in patients with Grade 2 tumors.

Preoperative KPS: When the functional status of the patients and its effect on survival time was assessed, it was found that, of the 60 cases with $K P S \geq 70,56$ patients (93.3\%) survived, and the median survival time was 87 months (95\% Cl: 81-93), whereas only $5(71.4 \%)$ of 7 patients with KPS $<70$ survived, and the median survival time was 71 months (95\% Cl: 44-97) in this group.

Postoperative KPS: Table II summarizes the relationship between survival rate, survival time, and postoperative KPS of the patients in the study cohort. When postoperative KPS and survival time were assessed together, of the 56 cases with $\mathrm{KPS} \geq 70,52$ patients survived during the follow-up period (between May 1998 and December 2005), and the median survival time was found to be $\mathbf{8 7}$ months $(95 \% \mathrm{Cl}: 80-$ 93 ) in these cases. In the sub-group of patients with KPS $<70$, 9 patients survived during the follow-up, and the median survival time was found to be 77 months (95\% Cl: 57-97) in this sub-group.

Functional localization of tumor: Of all the tumors, 13 were in an eloquent localization, while 54 were not. The median survival time of tumors in eloquent regions was 74 months (95\% Cl: 54-93), whereas it was 71 months (95\% Cl: 67-76) for those not in an eloquent region.
Contrast enhancement: In the study cohort consisting of 67 patients, 36 of 41 patients (61.2\%) without contrast enhancement survived, and the median survival time was 82 months (95\% Cl: 73-91), whereas 25 (96.2\%) of the 26 patients survived, and the median survival time was found to be 89 months (95\% Cl: 82-97). When the sub-groups were compared statistically, no significant difference was found in terns of survival time between the groups with and without contrast enhancement $(p>0.05)$.

Degree of resection (post-operative MRI): Degree of tumor resection on postoperative MRI, mean survival time, and statistical analysis are shown in Table II. 29 (96.7) of 30 patients who underwent gross total resection survived during the follow-up period. The median survival time was found to be 90 months (95\% Cl: 83-97) in this sub-group. Of the 37 patients who underwent subtotal resection, only 28 survived, and the median survival time was found to be 80 months $(95 \% \mathrm{Cl}: 70$ 91) in this sub-group.

Postoperative complications: The sub-group consisting of 41 patients without complications had a $90.2 \%$ survival rate during the follow-up, whereas survival rate was $92.3 \%$ in the sub-group consisting of remaining 26 patients. The median survival time was found to be 83 months (95\% Cl: 74-93) and 72 months (95\% Cl: 64-93), respectively.

Re-operation and survival rate: In the sub-group that consisted of 21 patients who underwent re-operation due to either recurrence or re-growth, the median survival time was found to be 74 months ( $95 \% \mathrm{Cl}: 67-81)$, and the survival rate was $95.2 \%$ (20 cases). In the other sub-group, which consisted of 41 patients without re-operation, these figures were 82 months (95\% Cl: $72-92)$ and $89.1 \%$. Although these results demonstrated that re-operation improved survival, the difference between sub-groups had no statistical significance ( $p>0.05$; Table II).

Malignant transformation: In Table III, the independent variables, malignant transformation rates, and statistical analysis are given. The median age in cases with malignant transformation was 35 years, ranging from 16 to 42 years. In the study cohort consisting of 67 patients, 8 (88.4\%) of 9 patients (13.4\%) with malignant transformation survived, and the median survival time was 68 months (95\% Cl: 55-81). $53(91.4 \%)$ of 58 patients without malignant transformation survived, and the median survival time was found to be 84 months (95\% Cl: 77-92). The patients with malignant transformation included $\mathbf{7}$ diffuse astrocytoma, 1 gemistocytic astrocytoma, and 1 pleomorphic xanthoastrocytoma (Table III). Although these results indicated that malignant transformation limited survival time, no statistical difference was found between the groups in terms of survival time ( $p>0.05$; Table II).

Degree of resection and malignant transformation: The malignant trasformation rate of the independent variables is given in Table III. When the gross total and sub-total resection on postoperative MRI and malignant transformation were 
Table III: Malignant Transformation Rate of Independent Variables

\begin{tabular}{|c|c|c|c|c|c|c|}
\hline \multirow{2}{*}{ Factors } & \multirow{2}{*}{ Variables } & \multirow{2}{*}{ n } & \multirow{2}{*}{$\begin{array}{c}\text { Survival rate } \\
\%\end{array}$} & \multicolumn{2}{|c|}{ Malignant transformation } & \multirow{2}{*}{$\mathbf{P}$} \\
\hline & & & & $n$ & $\%$ & \\
\hline \multirow{2}{*}{ Sex } & Male & 36 & 86.1 & 8 & 22.2 & \multirow{2}{*}{$<0.05$} \\
\hline & Female & 31 & 96.8 & 1 & 3.2 & \\
\hline \multirow{2}{*}{$\begin{array}{l}\text { Resection degree } \\
\text { (postoperative MR) }\end{array}$} & Gross total & 30 & 96.7 & 0 & 0 & \multirow{2}{*}{$<0.05$} \\
\hline & Subtotal & 37 & 86.5 & 9 & 24.3 & \\
\hline \multirow{2}{*}{ Second operation } & Yes & 21 & 95.2 & 9 & 42.6 & \multirow{2}{*}{$<0.01$} \\
\hline & No & 46 & 89.1 & 0 & 0 & \\
\hline \multirow{2}{*}{ Radiotherapy } & Yes & 17 & 88.1 & 7 & 41.2 & \multirow{2}{*}{$=0.01$} \\
\hline & No & 50 & 92.0 & 2 & 4.0 & \\
\hline \multirow{2}{*}{$\begin{array}{l}\text { Contrast } \\
\text { enhancement }\end{array}$} & Yes & 26 & 96.2 & 3 & 11.5 & \multirow{2}{*}{$>0.05$} \\
\hline & No & 41 & 87.8 & 6 & 14.6 & \\
\hline $\begin{array}{l}\text { Tumor subtypes } \\
\text { of malignant } \\
\text { transformation }\end{array}$ & $\begin{array}{l}\text { Diffuse astrocytoma } \\
\text { Gemistocytic astrocytoma } \\
\text { Pleomorphic xanthoastrocytoma }\end{array}$ & $\begin{array}{l}7 \\
1 \\
1\end{array}$ & & & & \\
\hline
\end{tabular}

analyzed together, it was found that there was no malignant transformation in 30 cases who were defined as gross total resection, whereas malignant transformation was detected in $9(24.3 \%)$ of 37 patients who were defined as sub-total resection. The difference between the groups was found to be statistically significant $(p<0.05)$.

Sex and malignant transformation: Of the 31 women $(46.3 \%)$ and 36 men $(53.7 \%)$ in the cohort, malignant transformation was detected in one (3.2\%) and 8 patients $(22.2 \%)$, respectively. The difference in favor of men was statistically significant $(p<0.05)$.

Re-operation and malignant transformation: Of the 67 patients, 21 patients underwent a second operation due to recurrence and residual tumor. Malignant transformation occurred in 9 of these patients. The difference was statistically significant $(p<0.01)$.

Radiotherapy and malignant transformation: Of the patients in the cohort, 50 patients $(74.6 \%)$ received no radiotherapy, while 17 patients (25.4\%) received postoperative radiotherapy. Malignant transformation was detected in 7 (41.2\%) of the patients given postoperative radiotherapy, while only 2 patients $(4.0 \%)$ displayed malignant transformation in the group that received no radiotherapy. A comparison of groups revealed a significant difference $(p=0.01)$ (Table III).

Contrast enhancement and malignant transformation: When contrast enhancement on preoperative MRI and malignant transformation were analyzed together, 3 patients with contrast enhancement displayed malignant transformation, while it occurred in 6 of 41 patients without contrast enhancement. No significant difference was found between the groups ( $p>0.05$ ).

\section{DISCUSSION}

Independent variables that affect survival, including age, sex, pre-and postoperative KPS, and functional localization, along with degree of resection, postoperative complications, malignant transformation, and factors that may affect malignant transformation such as age, sex, localization, surgical resection, and pathological diagnosis were statistically analyzed in the present study.

LGAs are commonly seen in the convexity of the brain. The frontal lobe is the most common localization, followed by the temporal lobe (27). In addition, they can occur in the basal ganglia and thalamus. However, the prognosis is poorer with such localization than for those localized in a hemisphere (14). Tumor localization against functional area is one of the important factors that affect resectability and, thus, the prognosis $(10,28)$.

The characteristic CT scan findings of LGAs include iso- to hypodense mass, which cannot be distinguished from surrounding tissues without prominent edema or mass effect. Non-enhancement after contrast material administration usually indicates an intact blood-brain barrier (50).

Enhancement of the lesion in CT scan after contrast material injection has been a matter of debate regarding its relationship to poor prognosis in cases with LGA. Although it was reported that contrast enhancement has no prognostic value in cases with LGA in a preliminary study (47), in a further, larger series, it was suggested that cases in which the tumor is enhanced on BT scan after contrast material injection had a poorer prognosis than those without enhancement. This finding was strongly supported by a retrospective study. According to this study, the tumor recurrence risk is 7-fold higher in cases with contrast enhancement than those without $(32,37)$.

According to these data, contrast enhancement on CT scan has great importance when assessing malignant transformation in cases with known tumors (2). Kelly et al. (21) showed that abnormal findings of the mass on T2-weighted sequences is 
more valuable than $\mathrm{CT}$ findings of the same lesion. Also, MRI provides more comprehensive information about contrast enhancement than CT scan (19).

Contrast enhancement in the resection area makes it difficult to assess contrasted MRI, which is performed to display postoperative residual tumor. Current recommendations suggest that MRI performed within 24-48 hours after surgery would be adequate for determining residual tumor (50). Winger et al. showed that the use of a corticosteroid might alter the pattern of contrast enhancement in tumors (30). Because steroids reduce the contrast enhancement of tumor and peri-tumoral edema, steroid use by patients should be considered when assessing recovery by MRI in cases of glioma (50). On MRI, lesions are seen as areas with low signal intensity on T1-weighed sequences, whereas it is almost always seen as areas with high signal intensity on T2-weighed images. Areas with increased signal are usually homogenous and well-defined, without evidence of hemorrhage or necrosis (17). In most cases, it is difficult to distinguish the tumor itself from the surrounding edematous tissue on MRI. Although not conclusive, small lesions may be detected using gadolinium on MRI (37).

Although there is a specific MRI pattern for LGAs (welldefined, homogenous, hypointense, and hyperintense gray matter thickening on $\mathrm{T} 1$ weighed and $\mathrm{T} 2$-weighed sequences, respectively), such a pattern is not always diagnostic for lowgrade tumors. A group of researchers performed a stereotactic biopsy study on 20 adults who had lesions suggesting LGA on $\mathrm{CT}$ and MRI scans. However, a histological evaluation revealed that, of these cases, only $50 \%$ had LGA, while $45 \%$ had anaplastic astrocytoma (24).

With this information together with that of other studies, one can conclude that contemporary high-resolution MRI alone cannot reliably justify a diagnosis of LGA; thus, histological confirmation is needed (37). MRI is unable to distinguish radiation necrosis and residual tumor from recurrent tumor. FDG-PET (F-2-fluoro-2-D-deoxyglucose-positron emission tomography) may be helpful in this discrimination. In PET scanning, a functional imaging modality, cerebral glucose activity is observed. Glucose activity is reduced in necrosis, whereas an increase is observed in recurrent tumor. LGAs display decreased metabolic activity similar to that of the surrounding gray matter (18).

In a study with MR spectroscopy, it was concluded that an increase in cholin levels over time is compatible to malignant degeneration in low-grade glioma (49). MR spectroscopy can map the energy metabolism of a certain area in the cranium (50). Although MR spectroscopy is unable to establish the histological grade of glial tumors, increased cholin uptake along with NAA values that are slightly lower or unchanged distinguish radiation necrosis from recurrent tumor, in favor of the latter rather than the former (46).

There is evidence suggesting a relationship between younger age and longer survival time in adult LGA cases $(6,10,28)$.
Therefore, the age of the patients is an independent variable that affects the choice of surgical method and, thus, survival. As age increases, the risk of death also increases. In contrast, aggressive treatment in elder patients is less effective than in younger patients in terms of improving survival $(5,6,23)$. In our study, the median survival time was found to be 89 months in patients younger than 40 years, while it was 64 months in 23 patients at 40 years old or older; this difference did not reach statistical significance $(p>0.05)$. Although the reasons for poorer outcomes in older patients compared to younger ones has not been fully elucidated, it could be due to patient tolerance for greater tumor mass without developing symptoms and a delay in diagnosis because of brain atrophy in older patients. However, the results of the present study suggest that patient age has no effect on prognosis. Despite this conclusion, we agree that age should be taken into account when assessing the role of aggressive surgical interventions on the life of the patient $(3,41,48)$.

Sex: In the literature, the percentage of male patients is reported to be $55-65 \%$ among patients with LGA (37). Of the 67 patients, 36 (54\%) were men in our study, while 31 (46\%) were women. This finding is in agreement with the literature. There are findings indicating poorer prognosis in women in the literature (26). In the present study, the survival rate was found to be $86 \%$, and the median survival time was 81 months in male patients, whereas these were found to be $96 \%$ and 72 months, respectively. Our findings support data in the literature $(26,37)$, but the difference has no significance.

Although the scoring system developed by Karnofsky (27) is commonly used in studies in the literature, a different scoring system used in some studies resulted in variety in the results $(6,10,16,28,36)$. Therefore, an undesirable heterogeneity exists among the results of the studies conducted on the prognostic value of performance status.

In the present study, the mean survival time was found to be 71 months in 7 patients with preoperative KPS $<70$, whereas it was 87 months in 60 patients with $K P S \geq 70$. Although our results demonstrated an association between higher preoperative KPS and better prognosis, it was not found to be statistically significant. It was found that the median survival time was 71 months in 7 patients with preoperative KPS $<70$, while it was 87 months in 60 patients with KPS $\geq 70$. Although our results demonstrated an association between higher preoperative KPS and better prognosis, it failed to reach statistical significance as an independent factor affecting survival. As the preoperative KPS determines the planned surgery type, the difference in outcomes obtained according to KPS may be due to the different scoring score systems used and an erroneous assessment of first performance $(8,35)$. Moreover, data about preoperative functional status were neglected in some studies, while no clinical information was provided about the preoperative clinical status of patients regarding aggressive surgical procedures $(4,42)$. Overall, when preoperative functional status was evaluated as an independent variable, it was reported that those outcomes were better in cases with high Karnofsky scores $(10,16,28)$. 
When preoperative KPS and degree of resection were considered as independent variables, it was found that the KPS score and type of surgery were closely related to patient survival (20). An important limitation of the relevant studies is the incorporation of a low preoperative KPS score, which has a significant relationship to higher mortality rates, in the statistical analysis, while not including the degree of resection, which appears to be a significant prognostic factor in multivariate analysis (16). On the contrary, Nelson et al. (36) suggested that both preoperative KPS and type of surgery are significantly related to survival. They also noted that varying degrees of resection accounted for no statistically significant difference regarding the survival time of patients.

In the present study, the median survival time was found to be 77 months in 11 patients with postoperative KPS $<70$, while it was calculated as $\underline{87}$ months in 56 patients with postoperative KPS $\geq 70$ during the follow-up period (between May 1998 and December 2005). It was concluded that, despite the fact that higher KPS after surgery correlated to longer survival, this factor was an independent variable that had no effect on prognosis. However, literature data indicating that preoperative KPS and degree of resection interplay with each other are still valid (6).

The optimal resection degree in any patient depends on the extent and localization of the tumor, the general and neurological status of the patient, and the experience of the surgeon $(6,28)$. In the assessment of the relationship between surgery and survival, it is widely accepted that tumor localization and degree of surgical resection depending on localization should be taken into account $(28,43)$.

In numeric studies on tumor extent, it has been reported that survival time improved as postoperative residual tumor volume decreased (40). Longer survival chance is obtained by aggressive cytoreductive surgery. There is almost consensus regarding the necessity of performing partial resection alone or a biopsy in the vulnerable areas of the brain to spare neurological functions. However, more extensive resections should be performed for lesions in invulnerable areas $(1,28)$. Salcman et al. advocated radical surgery based on a literature review of cases without adjuvant therapy, albeit not including tumor localization in the analysis $(39,42)$. Certainly, there is a need for a well-equipped operating room to perform radical surgery in patients.

In studies on common prognostic factors, it has been noted that the extent of resection had a favorable effect on survival $(1,5,6,11,22,28)$. However, opposing results regarding this controversial issue have also been found $(10,16,35)$. Aggressive resection is less relevant to improved survival in older patients $(6,23)$. In this study, the median survival time was found to be 90 months in 30 patients who underwent gross total resection, while it was 80 months in 37 patients who underwent sub-total resection. It was found that the degree of resection (gross total or sub-total) had no significant effect on the mean survival time of the patients.
In the present study, the mean survival time was found to be 71 months in cases with tumors localized in non-vital areas, whereas it was 74 months in those with tumors localized in vital areas. The effect of functional localization on survival time was insignificant. While tumor localization was implied as a valuable and effective variable regarding the prognostic point of view in most studies $(10,28,43)$, a few studies have proposed that localization had no effect $(10,22)$. Our study supports the latter.

In supratentorial LGAs, the degree of surgical resection is determined mostly by the localization and extent of the lesion. The desire to spare neurological functions resulted with a tendency to perform biopsy or partial resection in tumors in vital areas, whereas more aggressive resection has been performed with those localized in invulnerable areas (28). Thus, tumor localization should be taken into account as an independent variable that affects the degree of resection $(10,28,43)$. Coffey et al. (10) noted that tumor localization rather than type of surgery was an important prognostic factor that improves long-term outcomes. In some studies, tumor localization was not taken into account in analyzing data $(16,36,42)$, or tumor localization was analyzed and demonstrated as an independent factor that affected survival; however, the notion that tumor localization could affect an essential prognostic factor such as type of surgery was neglected (44).

In studies on the relationship between resection degree and long-term survival, tumor localization was considered independently and found to be ineffective in terms of prognostication, except for a few studies $(10,22,28,43)$. Most of the studies evaluating the effects of surgery on survival provided evidence supporting the notion that aggressive tumor resection was associated with improved prognosis $(10,22)$. Our findings suggest that tumor localization had no effect on aggressive tumor resection and that aggressive surgery could be achieved in any vital area with the assistance of neuronavigation-matched intra-operative sonography or MR techniques.

No contrast enhancement was seen in half of the LGAs, while mild peripheral contrast enhancement should be detected in $35-40 \%$ of the cases. Nodular areas with focal but intense contrast enhancement can be seen in the mass of LGA. Studies have shown that these focal areas may be compatible with high-grade tumor functions (37). Contrast material influx into the tumor may be explained by an impairment in the blood-brain barrier. The histopathological basis of contrast enhancement in a tumor is linked to pathological neo-vascularization and vascular endothelial proliferation. Therefore, poorer prognosis, which is associated with more severe contrast enhancement, may be related to pathological vascular enlargement (vascular endothelial proliferation) and impaired blood-brain barrier.

It was histopathologically confirmed that areas became more prominent after contrast material as a result of intense cellular and hypervascular texture of the tumor. Thus, the margins 
of enhancement indicate the macroscopic borders of the astrocytoma (1). In the present study, the median survival time was 89 months in 26 cases with contrast enhancement, while it was 82 months in 41 cases without enhancement; however, the difference failed to reach statistical significance. Malignant transformation was detected in only 3 (33.3\%) of 26 patients with contrast enhancement, whereas it was detected in $6(66.7 \%)$ patients without enhancement. These results support studies that have found no relationship between contrast enhancement and malignant transformation.

The issue of whether or not to perform re-operation due to the onset of novel symptoms and signs related to recurrent tumor in cases of LGA remains controversial. It has been proposed that the histopathological diagnosis, age, and KPS of the cases that underwent re-operation were effective with respect to quality of life rather than survival.

In the present study, there were 21 cases that underwent reoperation. It was found that cases were re-operated with the intention of gross total resection had no survival advantage when compared to those not re-operated due to re-growth. The median survival time was 74 months (95\% Cl:67-81) in patients who underwent re-operation, whereas it was 82 months (95\% \%: 72-92) in the remaining 46 patients. Our findings support the conception that re-operation due to recurrence did not improve the median survival time of cases by the desired level.

\section{Analysis of independent variables related to malignant transformation}

The transformation of LGA into a more malignant form has been the subject of several studies (37). In one a preliminary study, Muller et al. reviewed 72 patients diagnosed with astrocytoma by pathological evaluations. Of these tumors, $14 \%$ displayed no pathological change; $55 \%$ had transformed into anaplastic astrocytoma and $30 \%$ into glioblastoma multiform in the case of recurrence. They found that the time from the initial pathological diagnosis to the second operation was 31 months. These authors concluded that malignant transformation could be expected in approximately twothirds of all astrocytomas (including low-grade and anaplastic astrocytomas) (34). Another matter of debate is whether an anaplastic diagnosis obtained by a second biopsy or resection in a case previously diagnosed as LGA is due to the paucity of the initial specimen $(37,45)$.

An autopsy series of 129 cases with glioblastoma multiform was analyzed, and it was concluded that approximately $28 \%$ of these cases might have developed from previous astrocytoma (41). According to that study, the survival time in cases with LGA history is longer even after the transformation to anaplastic astrocytoma. However, it is shorter in de novo anaplastic cases (51). In another study on 77 cases with histologically proven LGA, no significant difference was found regarding the mean survival time between LGA cases with malignant transformation and those with de novo anaplastic astrocytoma (12).
The main reason for death in cases with LGA is usually malignant transformation of the tumor. The incidence of anaplastic regions in second biopsy specimens or autopsy series varies from $13 \%$ to $85 \%$ depending on the series. Recurrence may be due to malignant transformation or to missed anaplastic regions in the first histopathological evaluation $(15,44)$. Law et al. (29) found that the grade of cases was unchanged during follow-up in approximately half of patients, whereas it was upgraded in the remaining half. Firching et al. (13) found that although the rate of upgrading (9\%) was lower in Grade 1 astrocytoma, it was significantly higher in grade 2 cases (62\%).

In the 67 cases of the present study, 8 (88.9\%) of the 9 patients with malignant transformation survived, and the median survival time was 68 months, whereas 53 (91.4\%) of the 58 patients without malignant transformation survived, and the median survival time was 85 months. The malignant transformation rate was calculated as 13.4 in our study. When compared to the literature, the lower transformation rate in this study may be attributable to the fact that smaller residual tumors resulted from surgical intention to perform gross total resection.

Although no comprehensive studies have been conducted, one study has suggested increased frequency of malignant transformation in patients older than 40 years of age (25). In our study, the mean age in 9 cases with malignant transformation was 35 years, whereas it was 28 years in 58 patients without malignant transformation. Of the 31 women (46.3\%) and 36 men (53.7\%) in the study cohort, malignant transformation occurred in 01 and 8 patients, respectively. This difference was statistically significant. However, this finding is incongruous with the literature data (37).

Of the 67 patients in our study, lesions were localized in the frontal region in 15 patients (22.4\%). Malignant transformation occurred in 4 of 15 patients where lesions were localized in the frontal region. No malignant transformation was developed in any of the 13 patients with LGA localized in vital areas. This could be due to either more effective total resection in cases with LGA localized in vital areas or the biological behavior and features of these tumors.

When the gross total and sub-total resection on postoperative MRI and malignant transformation were analyzed together, it was found that there was no malignant transformation in 30 cases defined as gross total resection, whereas malignant transformation was detected in 9 of 37 patients who were defined as sub-total resection. According to these results, our study overlaps with the literature regarding total resection $(1,28)$.

Contrary to some LGAs, others have poorer prognosis and undergo rapid anaplastic change (41). In our study of 67 patients, 2 cases with gemiocytic astrocytoma and 2 cases with fibrillary astrocytoma were detected. Only 1 of the gemiocytic astrocytoma cases experienced malignant transformation after 19 months. A pleomorphic xanthoastrocytoma 
was detected in one case, which underwent malignant transformation and caused the death of the patient after 19 months.

When the intensity of the contrast enhancement on preoperative MRI and its effect of malignant transformation were analyzed, malignant transformation was found to have occurred in $3(11.5 \%)$ of 26 patients with contrast enhancement, while it was observed in 6 (14.6\%) of the 41 patients without contrast enhancement. Of the 9 patients who developed malignant transformation, 3 patients displayed contrast enhancement, while 6 did not; this is also in agreement with the literature, suggesting no relationship between malignant transformation and contrast enhancement.

It is a known fact that the aggressive surgery in low-grade tumors achieve a long life expectancy. Direct relationship between the amount of residual tumor and malignant transformation of tumor have been reported by Berger et al (7). In intraaxial tumors, the brain shift arising from debulking of the tumor, is one of the most important factors affecting the accuracy of the usage of intraoperative neuronavigation. Therefore, for the correction of the error rate generated in neuronavigation, the ultrasound images obtained intraoperatively for two or more dimentions, may be registered with the neuronavigation images, with a soft ware program offered by the manufacturer. With such a combination, the deviation of neuronavigation may be corrected significantly, and this facilitates resection of the remaining parts of the tumor in a secure way. However, the part of tumors extending to the vital and functional areas should be left as a residue in order to prevent neurological deficits, or be resected under the reliability of advanced technologies, such as awake surgery or intraoperative neuro-monitoring.

\section{CONCLUSION}

Our aim was to evaluate prognostic factors in LGA, as well as to designate a treatment method for LGA by investigating the contributions of the malignant transformation process. Although the relationship between prognosis and prognostic factors including age, sex, preoperative KPS, postoperative KPS, tumor localization, contrast enhancement, and mass effect is in agreement with widely accepted literature data, no statistical significance was found in our studies. In particular, in tumors localized in vital regions, no recurrence was observed, so no malignant transformation in cases that underwent total resection emphasized the importance of resection grade in LGA cases. The detection of higher malignant transformation rates in cases that underwent radiotherapy than those did not, and the statistical significance of this mandates the revision of the treatment plan regarding radiotherapy.

\section{REFERENCES}

1. Albert FK, Forsting $M$, Sartor K, Adams HP, Kunze S: Early postoperative magnetic resonance imaging after resection of malignant glioma: Objective evaluation of residual tumor and its influence on regwoth and prognosis. Neurosurgery 34: 45-61, 1994
2. Afra D, Osztie E: Histologically confirmed changes on CT of reoperated low-grade astrocytomas. Neuroradiology 39: 804-810, 1997

3. Ammirati M, Vick N, Liao YL, Ciric I, Mikhael M: Effect of the extent of surgical resection on survival and quality of life in patients with supratentorial glioblastomas and anaplastic astrocytomas. Neurosurgery 21: 201-206, 1987

4. Avellanosa AM, West CR, Tsukada Y, Higby DJ, Bakshi S, Reese $P A$, Jennings E: Chemotherapy of non irradiated malignant gliomas. Phase II: study of the combination of methyl-CCNU, vincristine, and procarbazine. Cancer 44: 839-846, 1979

5. Barker FG 2nd, Prados MD, Chang SM, Gutin PH, Lamborn KR, Larson DA, Malec MK, McDermott MW, Sneed PK, Wara WM, Wilson CB: Radiation response and survival time in patients with glioblastoma multiforme. J Neurosurg 84: 442-448, 1996

6. Barker FG 2nd, Chang SM, Larson DA, Sneed PK, Wara WM, Wilson CB, Prados MD: Age and radiation response in glioblastoma multiforme. Neurosurgery 49:1288-1297; discussion 1297-1298, 2001

7. Berger M, Wilson C (eds): The Gliomas. Philadelphia: W. B. Saunders, 1999

8. Byar DP, Green SB, Strike TA: Prognostic factors for malignant glioma, in Walker MD (ed): Oncology of the Nervous System. Boston: Martinus Nijhoff, 1983:379-395

9. Cairncross JG, Laperriere NJ: Low-grade glioma. To treat or not to treat? Arch Neurol 46: 1238-1239, 1989

10. Coffey RJ, Lunsford LD, Taylor FH: Survival after stereotactic biopsy of malignant gliomas. Neurosurgery 22: 465-473, 1988

11. Devaux BC, O'Fallen JR, Kelly PJ: Resection, biopsy, and survival parameters, therapy, and autome. J Neurosurg 78: 767-775, 1993

12. Dropcho EJ, Soong SJ: The prognostic impact of prior low grade histology in patients with anaplastic gliomas: A casecontrol study. Neurology 47:684-690, 1996

13. Firsching $R$, Tieben $R$, Schröder $R$, Stützer R: Long-term prognosis of low grade astrocytoma. Zentralbl Neurochir 55: 10-15, 1994

14. Franzini A, Leocata F, Cajola L, Servello D, Allegranza A, Broggi G: Low-grade glial tumors in basal ganglia and thalamus: Natural history and biological reappraisal. Neurosurgery 35 : 817-820; discussion 820-821, 1994

15. Garcia DM, Fulling KH, Marks JE: The value of radiation therapy in adution to surgery for astrocytoma of the adult cerebrum. Cancer 55: 919-927, 1985

16. Green SB, Byar DP, Walker MD, Pistenmaa DA, Alexander E Jr, Batzdorf U, Brooks WH, Hunt WE, Mealey J Jr, Odom GL, Paoletti P, Ransohoff J 2nd, Robertson JT, Selker RG, Shapiro WR, Smith KR Jr, Wilson CB, Strike TA: Comparisons of carmustine, procarbazine, and high-dose methyl prednisolone as additions to surgery and radiotherapy for the treatment of malignant glioma. Cancer Treat Rep 67:121-132, 1983

17. Johnson GA, Thompson MB, Drayer BP: Three-dimensional MRI microscopy of the normal rat brain. Magn Reson Med 4: 351-365, 1987

18. Ishikawa M, Kikuchi H, Miyatake S, Oda Y, Yonekura Y, Nishizawa S: Glucose consumption in recurrent gliomas. Neurosurgery 33:28-33, 1993 
19. Karim AB, Maat B, Hatlevoll R, Menten J, Rutten EH, Thomas DG, Mascarenhas F, Horiot JC, Parvinen LM, van Reijn M, Jager JJ, Fabrini MG, van Alphen AM, Hamers HP, Gaspar L, Noordman E, Pierart $M$, van Glabbeke $M$ : A randomized trial on dose-response in radiation therapy of low-grade cerebral glioma: European Organization for Research and Treatment of Cancer (EORTC) Study 22844. Int J Radiat Oncol Biol Phys 36: 549-556, 1996

20. Karnofsky DA, Burcheral JH: Inevaluation of Chemotherapy Agents, Macleod CM (ed). Newyork: Colombia University Pres, 1949:191-205

21. Kelly PJ, Daumas-Duport C, Kispert DB, Kall BA, Scheithauer BW, Illig JJ: Imaging-based stereotaxic serial biopsies in untreated intracranial glial neoplasms. J Neurosurg 66: 865-874, 1987

22. Kelly PJ: Stereotactic biopsy and resection of thalamic astrocytomas. Neurosurgery 25:185-195, 1989

23. Kelly PJ, Hunt C: The limited value of cytoreductive surgery in elderly patients with malignant gliomas. Neurosurgery 34 : 62-66, discussion 66-67, 1994

24. Kondziolka D, Lunsford LD, Martinez AJ: Unreliability of contemporary neurodiagnostic imaging in evaluating suspected adult supratentorial (low-grade) astrocytoma. J Neurosurg 79:533-536, 1993

25. Kopit WG, Klint RB: Mergers in healthcare: Can they be done? The lessons from Roanoke and Rockford. Interview by Michael B. Guthrie. J Health Care Mark 10: 47-52, 1990

26. Kreth FW, Faist M, Grau S, Ostertag CB: Interstitial 125I radiosurgery of supratentorial de novo WHO Grade 2 astrocytoma and oligoastrocytoma in adults: Long-term results and prognostic factors. Cancer 106:1372-1381, 2006

27. Krueger H, Conrady P, Zülch J: Special stresses at microscopy work places. Soz Praventiv Med 31:250-251, 1986

28. Lacroix M, Abi-Said D, Fourney DR, Gokaslan ZL, Shi W, DeMonte F, Lang FF, McCutcheon IE, Hassenbusch SJ, Holland E, Hess K, Michael C, Miller D, Sawaya R: A multivariate analysis of 416 patients with glioblastoma multiforme: Prognosis, extent of resection, and survival. J Neurosurg 95:190-198, 2001

29. Borgelt BB, Gelber RD, Larson M, Kramer S: Equivalence of radiation schedules for the palliative treatment of brain metastases in patients with favorable prognosis. Cancer 48 : 1749-1753, 1981

30. Leibel SA, Sheline GE, Wara WM, Boldrey EB, Nielsen SL: The role of radiation therapy in the treatment of astrocytomas. Cancer 35:1551-1557, 1975

31. Louis DN, Ohgaki $H$, Wiestler OD, Cavenee WK, Burger PC, Jouvet A, Scheithauer BW, Kleihues P: The 2007 WHO classification of tumours of the central nervous system. Acta Neuropathol 114:97-109, 2007

32. Mc Cormack BM, Miller DC, Budzilovich GN, Voorhees GJ, Ransohoff J:Treatment and survival of low-grade astrocytoma in adults-1977-1988. Neurosurgery 31:636-642; discussion 642,1992

33. Medbery CA 3rd, Straus KL, Steinberg SM, Cotelingam JD, Fisher WS: Low-grade astrocytomas: Treatment results and prognostic variables. Int J Radiat Oncol Biol Phys 15:837-841, 1988

34. Müller W, Afra D, Schröder R: Supratentorial recurrences of gliomas. Morphological studies in relation to time intervals with astrocytomas. Acta Neurochir (Wien) 37:75-91, 1977
35. Nazzaro JM, Neuwelt EA: The role of surgery in the management of supratentorial intermediate and high-grade astrocytomas in adults. J Neurosurg 73:331-344, Review, 1990

36. Nelson DF, Nelson JS, Davis DR, Chang CH, Griffin TW, Pajak TF: Survival and prognosis of patients with astrocytoma with atypical or anaplastic features. J Neuro Oncol 3:99-103, 1985

37. Neuberger JS, Ward-Smith P, Morantz RA, Tian C, Schmelzle $\mathrm{KH}$, Mayo MS, Chin TD: Brain cancer in a residential are a bordering on an oil refinery. Neuroepidemiology 22:46-56, 2003

38. Radhakrishnan VV, Saraswathy A, Rout D: Diffuse form of primary leptomeningeal gliomatosis-a case report. Indian J Pathol Microbiol 37 Suppl:S51-53, 1994

39. Ribom D, Eriksson A, Hartman $M$, Engler $H$, Nilsson $A$, Långström $B$, Bolander $H$, Bergström $M$, Smits $A$ : Positron emission tomography $C$-methionine and survival in patients with low-grade gliomas. Cancer 92:1541-1549, 2001

40. Rostomily RC, Spence AM, Duong D, McCormick K, Bland M, Berger MS: Multi modality management adult malignant gliomas. Neurosurgery 35:378-388, 1994

41. Russell DS, Rubinstein LJ: Ganglioglioma: A case with long history and malignant evolution. J Neuropathol Exp Neurol 21:185-193, 1962

42. Salcman M: Supratentorial gliomas: Clinical features and surgical therapy, in Wilkins RH, Rengachary SS (eds), Neurosurgery. Vol 1, New York: McGraw-Hill, 1985:579-590

43. Sawaya R, Hammoud M, Schoppa D, Hess KR, Wu SZ, Shi WM, Wildrick DM: Neurosurgical outcomes in a modern series of 400 craniotomies for treatment of parenchymal tumors. Neurosurgery 42:1044-1056, 1998

44. Scanlon PW, Taylor WF: Radiotherapy of intracranial astrocytomas: Analysis of 417 cases treated from 1960 through 1969. Neurosurgery 5:301-308, 1979

45. Schiffer D, Cavalla P, Chiò A, Richiardi P, Giordana MT: Proliferative activity and prognosis of low-grade astrocytomas. J Neuro Oncol 34:31-35, 1997

46. Scott GM, Gibberd FB: Epilepsy and other factors in the prognosis of gliomas. Acta Neurol Scand 61:227-239, 1980

47. Silverman C, Marks JE: Prognostic significance of contrast enhancement in low-grade astrocytomas of the adult cerebrum. Radiology 139:211-213, 1981

48. Simon RM: Desing and conduct of clinical trials, in Devita VT, Hellman S, Rosenberg SA (eds): Cancer, Principles and Pratica of Oncology, ed 2. Philadelphia: JB Lippincott, 1985:329-350

49. Tedeschi G, Lundbom N, Raman R, Bonavita S, Duyn JH, Alger JR, Di Chiro G: Increased choline signal coinciding with malignant degeneration of cerebral gliomas: A serial proton magnetic resonance spectroscopy imaging study. J Neurosurg 87:516-524, 1997

50. vanVeelen ML, Avezaat CJ, Kros JM, vanPutten W, Vecht C: Supratentorial low grade astrocytoma: Prognostic factors, dedifferentiation, and the issue of early versus late surgery. $J$ Neurol Neurosurg Psychiatry 64:581-587, 1998

51. Winger MJ, Macdonald DR, Cairncross JG: Supratentorial anaplastic gliomas in adults. The prognostic importance of extent of resection and prior low-grade glioma. J Neurosurg 71:487-493, 1989 